\title{
The Conceptual Model of a Web Learning Portal for Small and Medium Sized Enterprises
}

\author{
Celina M. Olszak and Ewa Ziemba \\ University of Economics, Katowice, Poland \\ olszak@ae.katowice.pl; ewa.ziemba@ae.katowice.pl
}

\begin{abstract}
The article aims at presenting a Web learning portal that allows for improving employees' competencies in implementation of the Internet related technologies in business. Such a portal is dedicated to small and medium sized enterprises (SMEs). The starting point for considerations is in suggesting initiatives that are necessary to undertake in the SME sector in the context of the knowledge based economy. Particular attention is paid to improving employees' competencies. Then SME needs related to improving knowledge and skills required to use the Internet in business are presented. In the context of the needs in question, a model of a Web learning portal dedicated to SMEs is suggested.
\end{abstract}

Key words: a Web learning portal, e-learning, internet technologies in business

\section{Introduction}

In the contemporary economy knowledge has become a basic and strategic resource. Improving employees' competencies that include knowledge and skills is now a must. A professional life of any employee is understood as a continuous process of learning and developing. Improving own competencies, employees show higher effectiveness of actions undertaken. Acquiring new knowledge and skills they are able to perform extra tasks (Awad, \& Ghaziri, 2004; Nonaka, $\&$ Takeuchi, 1995; Rivard, Aubert, Patry, Pare, \& Smith, 2004).

In the knowledge based economy much attention is paid to skills related to using information and communication technologies and tools (ICT) including the Internet in particular (Olszak, \& Ziemba, 2007; Turban, King, Lee, \& Viehland, 2004 ). Fostering appropriate conditions for improvement in ICT skills and knowledge is a crucial task for modern enterprises (especially for small and medium sized enterprises) that are going to raise effectiveness of their performance and that intend to be more competitive. Employees' knowledge and skill perfection is largely facilitated by Web learning portals.

Such portals are equipped with, among other things, functional modules including generation of

Material published as part of this publication, either on-line or in print, is copyrighted by the Informing Science Institute. Permission to make digital or paper copy of part or all of these works for personal or classroom use is granted without fee provided that the copies are not made or distributed for profit or commercial advantage AND that copies 1) bear this notice in full and 2) give the full citation on the first page. It is permissible to abstract these works so long as credit is given. To copy in all other cases or to republish or to post on a server or to redistribute to lists requires specific permission and payment of a fee. Contact Publisher@InformingScience.org to request redistribution permission. didactic materials, communication and co-operation with training course participants, knowledge assessment or reporting. Hence, the portals in question may be referred to as a complex electronic environment that supports improving employees' competencies.

Our paper aims at presenting a model of a Web Learning Portal as a tool for improving and evaluating SME employ- 
ees' competences in e-business. The starting point for considerations is in suggesting initiatives that are necessary to undertake in the SME sector in the context of the knowledge based economy (e-business initiatives in particular). Then some attention is paid to improving employees' competencies in e-business. Next SME needs related to improving knowledge and skills required to use the Internet in business are presented on the basis of survey analyses. In the context of the needs in question, a model of a Web learning portal dedicated to SMEs is suggested.

\section{Improving MSE Knowledge and Competencies in the Knowledge Based Economy}

Much attention is paid to SMEs strategies related to development of the knowledge based economy, which results, among other things, from the fact that SMEs play a major economic and social role, and therefore are a source of economic development ("Highlights from the 2003 Observatory...", 2004; "Fostering Entrepreneurship...", 2004). For instance, in Poland SMEs make up approximately $98 \%$ of all business entities and employ over $60 \%$ vocationally active Polish citizens. SMEs participate in generation of about $50 \%$ of the gross domestic product. Their share in export amounts to 45\%. In spite of their importance, SMEs are perceived to be hardly competitive and innovative (Luczka, 2007). That is why, numerous initiatives and assumptions that call for prompt realisation include, among other things, the following (Łuczak, 2007; Marchand, 2000); Olszak, \& Ziemba, 2007:

- an increase in innovativeness and competitiveness of the economy by means of ICT implementation. It is possible to provide much evidence confirming that enterprise that makes information technology oriented investments obtain substantial profits. Unfortunately, modern information technology related solutions are mainly oriented at large enterprises and corporations. Putting the latest information technology related solutions into practice of SMEs is frequently much delayed in comparison with large enterprises or does not happen at all. As a result, SMEs are not as competitive on the market as large enterprises and their development is questionable. Such a situation affects the whole economy and social relations of each country and mainly results from insufficient knowledge and experience of SMEs as far as implementation of the latest information and computer technologies are concerned;

- an increase in participation of SMEs in e-business. SMEs are not good enough at solving problems related to functioning in e-business. Numerous contemporary economic and social relations are of extraordinarily complex nature that is simply not known to SMEs. A good example here may be provided by interdependencies that characterise any external environment including, among other things, flexibility of target markets or costs of capital in the long time perspective. SMEs frequently focus on solving ongoing tasks and do not pay sufficient attention to modern techniques of enterprise management including for example knowledge management or ICT techniques. Moreover, SMEs are often not able to convert their own ideas into an actual product on their own and they cannot create an adequate research group; and

- development of diversified educational forms and programmes that are supposed to satisfy needs arisen from the knowledge based economy. A model of education is undergoing thorough valuation in the knowledge based economy. The paradigm that is based on factographic, mechanistic and linear knowledge acquisition and that is still in use is now being given up as a result of adopting new and creative teaching and training. Taking into consideration that a community in the knowledge based economy is highly mobile, both in time and space, different forms of electronic education should be widely implemented. 
Contents of such forms ought to be quickly adjusted to rapidly changing needs of the economy and employees have to be prepared to use ICT techniques.

It is assumed that development of SME competencies involves some change in the scope of knowledge and skills acquired by particular employees so that they could perform new or present tasks more effectively. There are numerous methods employed to expand knowledge and improve skills including the following (Filipowicz, 2004):

- training on the job;

- imitating, e.g. other employees or enterprises; and

- other training, i.e. providing employees with opportunities for development of their knowledge and skills.

A large role in improving competencies is now played by electronic training courses (Hadjerrouit, 2007; Jamali, 2005). E-learning solutions are supposed to remove limitations of a traditional teaching process and they help reduce costs related to knowledge acquisition in an enterprise. Elearning systems guarantee each worker to gain some access to all indispensable knowledge in the most convenient time (convenient for particular employees and their enterprises) and in the most convenient place (at work or at home). Such solutions do not require sending an employee to a place where some training is supposed to take place and therefore no employee has to be excluded from everyday responsibilities or decision making processes. Moreover, e-learning oriented training courses ensure individualisation of teaching processes as a result of possibilities to adjust the scope, intensity, tempo and level of a particular programme to needs of an enterprise and employees. The programmes in question make it possible to use knowledge provided many times as well. There is some free access to dedicated training materials and additional support available. Employees may attend training courses or try to complete their knowledge in a situation when they are required to perform a specific task that calls for new skill acquisition or improvement of those already acquired.

It is necessary to note down that the time required to obtain a desired level of competencies in case of each employee is different because people vary and their talents, intelligence or methods used while acquiring information are different. Therefore, it is recommended to undertake actions that aim at providing employees with training courses that are going to enable the employees in question to combine theoretical knowledge with some practical application. What is more, such training courses have to be adequate demographically and psychologically.

\section{MSE Needs Concerning Improvement of Knowledge Related to Opportunities for Employing the Internet in Business}

\section{Research Methodology of Training Related Needs}

A diagnosis of training related needs is a launch pad for designing a training course that would enable an enterprise to realise already set directions of employee development (Lewis, \& Whitlock, 2003). Experts suggest many diagnosis methods that may be applied while verifying training related needs in an enterprise (Event Profit, 2007; Hadjerrouit, 2007). A questionnaire that requires answering specific questions, ticking right options or filling in specific tables independently is the most frequently applied technique. A questionnaire may be filled in by the very participants of a training course or by their direct superiors or managerial staff of an enterprise. It is possible to use the Internet to perform a questionnaire or a questionnaire may be given to potential respondents directly and then it is frequently accompanied by an interview with potential 
training course participants or managers of an enterprise subject to research. A so called 'focus group' is another form used to diagnose training related needs. A focus group involves an interview made with the whole target group or its representative part. Interviews may be made during workshops that aim at collecting information on training course participants' expectations. There are other forms available, i.e. coaching that particularly involves mentoring carried out by competent individuals (Stone, 2007). In case of particular projects so called 'pre-tests' and 'past-tests' are frequently used. Such tests usually take form of a test that includes multiple choice questions and wh-questions. Such a test measures employees' knowledge and skills before and/or after training courses (effectiveness of employees' knowledge acquisition). This type of questionnairebased research may verify a level of knowledge, experience and competencies that concern a particular domain.

Some of the methods presented above are applied simultaneously although one or two (less frequently) methods are used. Employing at least two methods, it is possible to verify information obtained and - probably - explain some inaccuracies or even inconsistencies. As a result, there is an increase in probability that the most accurate diagnosis of a particular situation will be obtained. All such actions are undertaken to adjust a particular training course to needs of the whole enterprise and to expectations of all employees or employee teams more effectively.

In order to identify small and medium enterprises' demand for training courses related to implementation of the Internet technologies in business, some questionnaire research along with interviews (in case of some respondents only) was carried out. The questionnaire employed pre-test principles, which allowed for assessing the employees' up-to-date level of knowledge related to implementing Internet technologies in business. The analysis of the research results was a starting point and a launch pad for a design project dedicated to a training system that aimed at providing enterprises with some knowledge of how to implement and utilise Internet technologies in business activities carried out.

The questionnaire was designed to allow for determining the current situation of Internet technology utilisation in SMEs along with an up-to-date level of SME knowledge of opportunities for utilising Internet technologies in business and for diagnosing needs for further improvement in the related knowledge.

\section{Description of the Sample Subject to Research}

The questionnaire based research involved approximately 170 small and medium enterprises that had already been consulted directly with reference to the research project carried out and the questionnaire objectives. It is necessary to pay attention to the fact that 300 enterprises were invited to participate in the research but only 170 decided to accept the invitation. All enterprises that made up the group subject to research are based in Upper Silesia or their branches are based there - in the most industrialised and densely populated region of Poland.

The sample subject to research comprised of commerce, production and service related enterprises. The greatest interest in the questionnaire was shown by information technology enterprises - $27 \%$ of questionnaires came from this sector. Such a situation obviously affect the results of analyses carried out because information technology enterprises have more extensive knowledge of how to apply Internet technologies in business and as compared to other enterprises they more frequently utilise the technology in question. Other sectors involved in the research included enterprises of the automotive (13\%), construction (11\%), financial (11\%), legal and consulting (8\%) and tourist (5\%) profile. The largest part of enterprises analysed (almost $48 \%$ ) is made up of business entities that employ up to 50 people. $21 \%$ of enterprises subject to the research employ from 51 to 250 people. 
Answers were mainly provided by owners and co-owners of enterprises along with their chief information officers and chief executive officers.

The questionnaire analysis was carried out by means of the Statistical Package for the Social Science for Windows - comprehensive statistical software used for data analyses, data management, etc.

\section{Applications of Internet Technologies in Business in the SME Sector}

Questionnaire related research carried out allowed for determining how (levels) and where (business areas) small and medium sized enterprises used Internet technologies. It turns out that small and medium enterprises employ the Internet and Internet based technologies but actions undertaken in this field are not very common. Enterprises mainly use Internet technologies to support business relations with their customers and partners. Internet technologies are the most frequently implemented to support marketing activities predominantly including promotion of an enterprise and its products or image. Direct sale is less frequently offered in the Internet environment and if it is, it is mainly carried out by means of own Internet outlets. Some attention has to be paid to the fact that enterprises recognise a necessity for implementing Internet technologies to support information provision in their supply chains and in case of order and delivery realisation. While dealing with financial institutions, electronic transfers predominate. With reference to government administration offices, electronic settlement returns are sent to the National Insurance. Enterprises often use different forms that are uploaded by public administration offices in the Internet. As a result of the analyses carried out, it is possible to observe that Internet technology utilisation in small and medium enterprises is insufficient, and it is necessary to undertake some actions that would aim at popularising the business use of the Internet. Selected research results concerning utilisation of the Internet technologies in business are presented in Appendix A.

\section{SME Knowledge of Opportunities for Utilising Internet Technologies in Business}

Another group of questions allowed for diagnosing SME knowledge of opportunities for using Internet technologies in business. Generally, a majority of enterprises demonstrate some knowledge of legal aspects of Internet technology applications in business along with threats and security related issues to be faced while applying Internet technologies in business. However, such knowledge is not always thorough and sufficient enough to implement and use the Internet in business effectively. More than a half of enterprises cannot effectively implement e-business strategies that require carrying out organisational and business changes. There are numerous barriers to be dealt with here and the most important ones include lack of knowledge related to Internet technologies, no experience of applying Internet technologies in business, lack of knowledge related to opportunities for using Internet technologies in business and no idea how to use Internet technologies in business. More than a half of enterprises in question do believe that their knowledge of implementing and applying Internet technologies in business is insufficient. Selected research results concerning small and medium enterprises' knowledge of opportunities for using Internet technologies in business are presented in Appendix B.

\section{Needs for Improving SME Knowledge of Opportunities for Using Internet Technologies in Business}

A third group of questions was devoted to a need for improving SME knowledge of opportunities for using Internet technologies in business. The research carried out revealed that only a few enterprises provided their employees with ongoing training courses. Such courses mainly include 
in-house training courses carried out by an external expert (approximately 11\%) and training courses in the Internet (approximately 11\%) (see Table 1).

Table 1. Types of training courses carried out in enterprises

\begin{tabular}{|l|c|c|}
\hline \multicolumn{1}{|c|}{ Types of training courses } & Total & Total \% \\
\hline In-house training courses carried out by an external expert & 18 & $10.60 \%$ \\
\hline Internet assisted training courses & 18 & $10.60 \%$ \\
\hline In-house training courses carried out by an internal expert & 12 & $7.10 \%$ \\
\hline Direct consulting and consultations & 9 & $5.30 \%$ \\
\hline Internet assisted consulting and consultations & 6 & $3.50 \%$ \\
\hline CD-ROM assisted independent learning & 5 & $2.90 \%$ \\
\hline
\end{tabular}

Although enterprises rarely provide their employees with training courses they understand a major role of such courses for business success. Almost $86 \%$ of enterprises agree that a training course related to applying Internet technologies in business may play a key role in business success of an enterprise (see Table 2).

Table 2. A role of training courses in business success of an enterprise

\begin{tabular}{|l|r|r|}
\hline \multicolumn{1}{|c|}{ Role of training courses } & Total & Total \% \\
\hline Important & 80 & $47.10 \%$ \\
\hline Very important & 47 & $27.60 \%$ \\
\hline Not very important & 20 & $11.80 \%$ \\
\hline Major & 19 & $11.20 \%$ \\
\hline Irrelevant & 4 & $2.40 \%$ \\
\hline
\end{tabular}

First of all, SMEs prefer in-house training courses that are carried out by external experts (107 enterprises, approximately 63\%). Internet training courses or courses that employ CD-ROMs would, however, be introduced by 47 enterprise (approximately 28\%) (see Table 3). Such opinions may result from the fact that enterprises do not trust or know opportunities for training offered by the Internet. Such a conclusion is also reached having made direct interviews with some respondents who demonstrated knowledge of neither opportunities offered by electronic training courses nor such training advantages or disadvantages. Therefore, enterprises would have to be made aware of all training related opportunities created by the Internet.

Table 3. Types of training courses in demand with reference to enterprises

\begin{tabular}{|l|c|c|}
\hline \multicolumn{1}{|c|}{ Types of training courses } & Total & Total \% \\
\hline In-house training courses carried out by an external expert & 107 & $62.90 \%$ \\
\hline Direct consulting and consultations & 37 & $21.80 \%$ \\
\hline Internet assisted training courses & 25 & $14.70 \%$ \\
\hline Internet assisted consulting and consultations & 24 & $14.10 \%$ \\
\hline In-house training courses carried out by an internal expert & 22 & $12.90 \%$ \\
\hline CD-ROM assisted independent learning & 22 & $12.90 \%$ \\
\hline
\end{tabular}


The careful selection of a training method is a vital or fundamental question for designing electronic training courses. There are some methods that are used in traditional teaching but they can hardly find their application in e-learning. Therefore, only the forms that could be employed best in electronic training courses dedicated to enterprise employees were included in the questionnaire (i.e. theoretical lectures, case studies, learning from knowledge libraries, etc.). The vast majority of enterprises (approximately 72\%) believe that theoretical lectures based on practical examples are the most useful training method. Case study presentations find fewer supporters (approximately 35\%) and theoretical lectures hardly enjoy any popularity (approximately 12\%) (see Table 4).

Table 4. Teaching methods to be used while carrying out electronic training courses

\begin{tabular}{|l|c|c|}
\hline \multicolumn{1}{|c|}{ Teaching methods } & Total & Total \% \\
\hline Theory based lectures illustrated with anecdotal evidence & 123 & $72.40 \%$ \\
\hline Presentations of case studies & 59 & $34.70 \%$ \\
\hline Internet access to appropriate bibliographic resources & 28 & $16.50 \%$ \\
\hline Theory based lectures & 21 & $12.40 \%$ \\
\hline
\end{tabular}

The research demonstrated that a majority of enterprises were interested in a training course devoted to Internet technology applications in business. However, thematic scopes and levels of selected training courses were diversified. Much attention was predominantly focused on the following issues: security of Internet technology applications, electronic commerce, legal aspects of employing Internet technologies in business, strategies of employing Internet technologies in business and electronic marketing. Enterprises mainly voice their demand for elementary or intermediate training courses. The detailed analysis of demand for particular topics and levels of training is presented in Table 5.

Table 5. A suggested thematic scope of trainings

\begin{tabular}{|l|c|c|}
\hline \multicolumn{1}{|c|}{ Thematic scope } & Total & Total \% \\
\hline Security of implementing Internet technologies in business & 112 & $65.88 \%$ \\
\hline E-commerce & 108 & $63.53 \%$ \\
\hline Legal aspects of implementing Internet technologies in business & 105 & $61.76 \%$ \\
\hline Electronic marketing & 104 & $61.18 \%$ \\
\hline Planning a strategy of implementing Internet technologies in business & 102 & $60.00 \%$ \\
\hline Data mining & 97 & $57.06 \%$ \\
\hline Electronic administration & 96 & $56.47 \%$ \\
\hline Electronic banking and finance & 94 & $55.29 \%$ \\
\hline Electronic logistics systems & 93 & $54.71 \%$ \\
\hline Data warehouses and multidimensional data analyses & 91 & $53.53 \%$ \\
\hline Business Intelligence Systems & 85 & $50.00 \%$ \\
\hline Corporate portals & 84 & $49.41 \%$ \\
\hline Electronic trainings & 83 & $48.82 \%$ \\
\hline Content management systems & 82 & $48.24 \%$ \\
\hline
\end{tabular}




\section{A Model of a Web Learning Portal}

\section{Functionality of a Web Learning Portal}

Analyses and diagnoses of the existing knowledge and training needs allow for designing a form of training that complies with the requirements and expectations of SMEs.

Enterprises prefer traditional training run by an external expert. However, interviews made with selected enterprises showed that the enterprises in question did not have any knowledge of electronic training and that they were afraid of all the difficulties that might emerge. That is why, it is necessary to inform SMEs of opportunities that are offered by electronic training and to present advantages and disadvantages of electronic training in the context of employee competence improvement.

The analyses carried out confirmed that theoretical lectures based on anecdotal evidence turned out to be a desired form of potential training. Training contents should particularly refer to commerce, production and services related activities.

It is also necessary to pay attention to the fact that SMEs are interested in trainings of different advancement levels, i.e. trainings aimed at beginners and intermediate or proficient users (Röder, 2003).

The research carried out - supported by the literature analysis (Discenza, Howard, \& Schenk, 2002; Fallon, \& Brown, 2003; Lewis, \& Whitlock, 2003) - was a launch pad for creating a model of a learning portal aimed at SMEs that would like to find out more about applications of Internet technologies in business. The research confirmed that such a training course should include the following components:

- didactic materials in form of a lecture whose contents would refer to opportunities for using Internet technologies in business;

- practical examples and solutions that expand knowledge and skills of implementing and using Internet technologies in business;

- tools that check a level of knowledge and skills acquired by SMEs with reference to implementing and using Internet technologies in business;

- communication tools that allow for tutor's contacts with training course participants and let participants get in touch with other participants;

- reports that would allow for monitoring work and progress of training course participants;

- a search system that would allow for finding necessary knowledge; and

- tools that are used while designing didactic materials.

In this situation a Web learning portal was assumed to include the following modules:

- a module used for knowledge provision;

- a module used for knowledge assessment;

- a module used for communication;

- a module used for searching;

- a module used for generating didactic materials; and

- a module used for reporting. 


\section{A module used for knowledge provision}

A module of knowledge provision consists of three levels of advancement applied while acquiring knowledge and skills: basic, intermediate and advance levels.

An elementary level involves a didactic method in form of a lecture that encourages hypothetical and deductive thinking of participants. Lectures are presented in thematic groups according to needs voiced by small and medium enterprises (see Table 5).

The structure of each lecture consists of the following parts:

- an introductory part: familiarising participants with the subject of the lecture, presenting a plan of the lecture, defining key notions, etc.;

- a major part: discussing the scope of the lecture, presenting theses and evidence in predefined sequence;

- a concluding part: a synthetic overview of contents presented, highlighting important elements in form of general principles and formulas;

- a controlling part: a set of problem questions to be answered by training course participants after a particular thematic unit has been completed; and

- a bibliographic part: all relevant literature and links to Internet websites that contain additional information on issues presented in a particular lecture.

Any intermediate level of a knowledge provision module consists of case studies that are based on practical examples of implementing and using Internet technologies in business (Dul, \& Hak, 2007). Case studies aim at developing decision making skills and solving own problems by means of selecting analogue cases. Case studies ought to show the way enterprises may implement and apply Internet technologies in business. Moreover, case studies should also refer to activities undertaken on all management levels: strategic management, tactical management and operational management.

It seems that an advanced level module of knowledge provision is extremely useful for SMEs. Such a module provides for an opportunity to work on case study analyses that are subsequently presented by training course participants in their newsgroups in order to exchange opinions with a tutor and other participants. This level of a training course aims at developing skills and supporting potential solutions of decision making related problems.

\section{A module of knowledge assessment}

Considering the fact that control and self-assessment of knowledge are some of elements of learning, a module of knowledge assessment was intended to be a part of a Web learning portal. Knowledge assessment involves standardised single choice tests. It seems that this type of exercises checks participants' knowledge sufficiently. However, while working on questions that are going to be used in a particular knowledge assessment module, it is necessary to pay much attention to clarity and lack of ambiguity of both questions and answers. Correctly written tests allow their users to check cognitive and analytic skills of training course participants. In a module of knowledge assessment, tests were divided into three thematic groups on the basis of all needs that were voiced by small and medium enterprises (see Table 5).

When a learner completes a test, a system generates a point and percentage assessment of answers provided (a ratio of good answers to a general number of answers provided). Additionally, all questions along with their answers are displayed - correct answers are shown along with all answers selected by a learner. As a result, training course participants may compare their own answers with the correct ones. 


\section{A communication module}

A communication module of a Web learning portal is suggested to provide the following applications:

- a newsgroup with pre-defined topics that correspond with a training course thematic scope and with a function that allows tutors and training course participants to create their own themes and posts;

- a communicator that is going to be used by all training course participants and their tutors in the so-called chat rooms; and

- an electronic newsletter that includes information on new items in a knowledge portal, tasks to be performed, etc. and that is sent by e-mail to all training course participants who have already subscribed for such a service.

A communication module allows, first of all, for realisation of tasks that are attributed to a tutor responsible for monitoring individual work of training course participants. Major responsibilities to be faced by a tutor include the following (Ziemba, 2004):

- checking exercises completed by training course participants;

- providing training course participants with information on didactic objectives;

- answering questions;

- dealing with correspondence with training course participants;

- advising and consulting; and

- moderating discussions.

A tutor is responsible for ongoing contacts with training course participants and for providing them with appropriate conditions for knowledge acquisition. The very knowledge transfer is not enough. A tutor is also responsible for developing training course participants' skills necessary while using media as tools of intellectual work.

\section{A searching module}

A searching module is responsible for enabling users to navigate a portal. The portal in question is planned to include the following solutions:

- a portal map that is going to provide condensed hyperlink sets and information in form of some overview of the whole training portal;

- a portal index that will alphabetically provide ordered lists of hyperlinks used for the portal contents;

- a system of context hyperlinks that are usually placed in the text and that will make it easy to move between correlated or similar information; and

- a search engine that will on the basis of appropriate queries provide sets of automatically found search results that correspond closely to the queries.

\section{A module for didactic material generation}

In order to ensure flexible uploading and updating of didactic contents in form of lectures or case studies, the portal structure provides for a module that is used to generate didactic materials. The module in question functions in a similar way to word processing software being in use contemporarily. 
Generation of didactic materials for electronic training courses poses new challenges to teachers because it requires a new poly-semiotic approach to media. Therefore, a new role of a teacher emerges: it is not enough for a teacher to be a designer - he or she has to be a technologist as well. A role of a teacher-designer mainly involves determining teaching concepts (programme concepts, teaching methods, etc.) and preparing didactic materials professionally. However, a teacher-technologist has to translate all didactic materials provided by a teacher-designer into multimedia and disseminate such materials by means of currently available information tools and technologies.

A module used for creating didactic materials is responsible for supporting work undertaken by a teacher-designer and a teacher-technologist.

\section{A reporting module}

A reporting module allows training course providers and participants for obtaining information on a training process, e.g. a training cycle for each participant, time spent on training, sequence of using particular didactic materials, etc. Such reports would allow for assessing how and how often a portal is used. The reports in question may also be some incentive or a hint to be used while implementing changes to satisfy learners' needs more effectively.

\section{Implementation of a Web Learning Portal}

In order to build a portal a concept of programming frameworks was used. Frameworks support creating, developing and testing applications. A software framework is a reusable design for a software system (or subsystem). This is expressed as a set of abstract classes and the way their instances collaborate for a specific type of software. Software frameworks can be object-oriented designs. Although designs do not have to be implemented in an object-oriented language, they usually are and in some ways they can be considered the object-oriented equivalent of software libraries. A software framework may include support programs, code libraries, a scripting language, or other software to help develop and glue together the different components of a software project. Various parts of the framework may be exposed through an application programming interface ("Framework", 2007).

The Web learning portal to be designed implements programming frameworks that support the PHP script language, i.e. ZEND and SFH_FORM_FRAMEWORK.

The Web learning portal is currently being completed. The prototype is planned to be verified by its users in the first half of 2008. Users that are supposed to test the prototype will include extramural students who are simultaneously employees of the small and medium enterprise sector.

\section{Conclusions}

The knowledge based economy requires a different approach towards processes of teaching and improving knowledge or competencies (Horton, \& Horton, 2003). Traditional methods decrease in importance and they are being replaced with new techniques based on, among other things, Web learning portals. Web learning portals allow for effective and flexible management of training materials. Moreover, such portals provide friendly mechanisms to carry out remote trainings and give a transparent and thorough picture of skills acquired by particular employees or teams. It seems that the suggested concept of a Web learning portal relatively comprehensively satisfies small and medium enterprises' expectations referring to opportunities for Internet technology utilisation in business. Further portal related works will focus on implementing more complex case studies. Assessment of teaching effectiveness is another important task to be dealt with in the nearest future. 
Providing small and medium enterprises with a Web learning portal may, according to the authors, contribute to some increase in a number of enterprises that utilise Internet technologies. Additionally, risk related to copying wrong solutions is going to decrease, procedures related to utilisation of Internet tools may get more effective and know-how transfers may be characterised by higher efficiency. Finally a knowledge portal may influence improvement in the whole SME sector, which will definitely result in some increase in SME competitiveness.

\section{References}

Awad, E. M., \& Ghaziri, H. M. (2004). Knowledge management. Englewood Cliffs: Pearson-Prentice Hall.

Discenza, R., Howard, C., \& Schenk, K. (2002). The design \& management of effective distance learning programs. London: Idea Group.

Dul, J., \& Hak, T. (2007). Case study methodology in business research. Oxford: Elsevier.

Event Profit. (2007). Diagnoza potrzeb szkoleniowych firmy. Ankieta lub warsztaty, Retrieved September 10, 2007, from http://www.profes.com.pl/publikacje/media_2006_04_event.html

Fallon, C., \& Brown, S. (2003). E-learning standards. A guide to purchasing, developing and deploying standards - Conformant e-Learning. New York: St Lucie Press.

Filipowicz, G. (2004). Zarzqdzanie kompetencjami zawodowymi. Warszawa: PWE.

Fostering entrepreneurship and firm creation as a driver of growth in a global economy. (2004). Turkey: OECD.

Framework. (2007). Retrieved September 10, 2007, from http://pl.wikipedia.org/wiki/Framework

Hadjerrouit, S. (2007). Applying a system development approach to translate educational requirements into e-learning. Interdisciplinary Journal of Knowledge and Learning Objects, 3, 107-134. Santa Rosa: Informing Science Institute. Retrieved from http://ijello.org/Volume3/IJKLOv3p107-134Hadj296.pdf

Highlights from the 2003 Observatory. (2004). 2003 Observatory of the European SMEs. European Commission.

Horton, W., \& Horton, K. (2003). E-learning tools and technologies: A consumer's guide for trainers, teachers, educators, and instructional designers. Indianapolis: Wiley Publishing.

Jamali, D. (2005). Changing management paradigms: Implication for educational institutions. Journal of Management Development, 24.

Lewis, R., \& Whitlock, Q. (2003). How to plan and manage an e-learning programme. Burlington: Gower Publishing.

Łuczka, T., et al. (2007). Mate i średnie przedsiębiorstwa. Szkice o wspótczesnej przedsiębiorczości. Poznań: Wydawnictwo Politechniki Poznańskiej.

Marchand, D. A. (2000). Competing with information. A manager's guide to creating business value with information content. Chichester: John Wiley \& Sons.

Nonaka, I., \& Takeuchi, H. (1995). The knowledge-creating company. New York: Oxford University Press.

Olszak, C. M., \& Ziemba, E. (2007). Strategie i modele gospodarki elektronicznej. Warszawa: PWN.

Philips, P. (2003). E-business strategy. Text and cases. New York: McGraw-Hill Education.

Rivard, S., Aubert, B. A., Patry, M., Pare, G., \& Smith, H. A. (2004). Information technology and organizational transformation. London: Elsevier.

Rőder, S. (2003). Eine Architektur für individualisierte computergestützte Lernumgebungen. Frankfurt a. M.: Lang.

Stone, F. M. (2007). Coaching, counseling \& mentoring: How to choose \& use the right technique to boost employee performance. New York: AMACOM. 
Turban, E., King, D., Lee, J., \& Viehland, D. (2004). Electronic commerce. A managerial perspective. New Jersey: Prentice Hall.

Ziemba, E. (2004). E-learning w procesie współczesnego kształcenia. In: Pozyskiwanie wiedzy i zarzqdzanie wiedza. Edited by Nycz, M., Owoc, M. \& Nowicki, A. Wrocław: AE.

\section{Appendix A. Implementations of Internet Technologies in Business of SMEs - Results of the Questionnaire Based Research}

Question 1. Does your enterprise use Internet technologies in B2B, B2B, B2A, B2E and E2E relationships?

\begin{tabular}{|l|r|c|}
\hline & Total & Total \% \\
\hline B2C (business-customer) & 92 & $54.10 \%$ \\
\hline B2B (business-business) & 82 & $48.20 \%$ \\
\hline B2A (business-administration) & 42 & $24.70 \%$ \\
\hline B2E (business-employee) & 47 & $27.70 \%$ \\
\hline E2E (employee-employee) & 42 & $24.70 \%$ \\
\hline
\end{tabular}

Question 2. Does your enterprise use Internet technologies in marketing activities?

\begin{tabular}{|l|c|c|}
\hline & Total & Total \% \\
\hline Internet promotion using own website & 103 & $60.60 \%$ \\
\hline $\begin{array}{l}\text { Creating corporate and product image by } \\
\text { means of own website }\end{array}$ & 67 & $39.40 \%$ \\
\hline Internet promotion using other websites & 33 & $19.40 \%$ \\
\hline $\begin{array}{l}\text { Creating corporate and product image by } \\
\text { means of other websites }\end{array}$ & 18 & $10.60 \%$ \\
\hline
\end{tabular}

Question 3. Does your enterprise use Internet technologies in direct sale?

\begin{tabular}{|l|r|r|}
\hline & Total & Total \% \\
\hline Own Internet outlet & 28 & $16.50 \%$ \\
\hline Internet auctions & 14 & $8.20 \%$ \\
\hline Internet tenders & 13 & $7.60 \%$ \\
\hline Internet markets & 3 & $1.80 \%$ \\
\hline Internet outlet in an Internet mall & 2 & $1.20 \%$ \\
\hline
\end{tabular}


Question 4. Does your enterprise use Internet technologies to support the supply chain?

\begin{tabular}{|l|c|c|}
\hline & Total & Total \% \\
\hline Ensuring information in the supply chain & 50 & $29.40 \%$ \\
\hline Realizing orders and delivery & 47 & $27.60 \%$ \\
\hline Providing customers with opportunities for placing orders & 37 & $21.80 \%$ \\
\hline Negotiating prices and conditions of contracts with partners & 35 & $20.60 \%$ \\
\hline Managing relationships with suppliers & 25 & $14.70 \%$ \\
\hline receiving customers' payments & 21 & $12.40 \%$ \\
\hline Advance planning and scheduling & 19 & $11.20 \%$ \\
\hline
\end{tabular}

Question 5. Does your company use Internet technologies to support contacts with banks and other financial institutions?

\begin{tabular}{|l|r|c|}
\hline & Total & Total \% \\
\hline Electronic transfers & 146 & $85.90 \%$ \\
\hline Credit, debit and charge cards & 62 & $36.50 \%$ \\
\hline Exchange of correspondence with banks and other financial institutions & 40 & $23.50 \%$ \\
\hline Electronic money & 20 & $11.80 \%$ \\
\hline Making transactions on the stock exchange market & 9 & $5.30 \%$ \\
\hline E-mail payments & 7 & $4.10 \%$ \\
\hline SMS payments & 5 & $2.90 \%$ \\
\hline
\end{tabular}

Question 6. Does your company use Internet technologies to support relationships with tax offices, customs offices and National Insurance?

\begin{tabular}{|l|c|c|}
\hline & Total & Total \% \\
\hline Sending declarations to National Insurance & 114 & $67.10 \%$ \\
\hline Settling fiscal liabilities & 55 & $32.40 \%$ \\
\hline Settling National Insurance liabilities & 46 & $27.10 \%$ \\
\hline Sending tax returns & 43 & $25.30 \%$ \\
\hline $\begin{array}{l}\text { Exchange of correspondence with National Insur- } \\
\text { ance }\end{array}$ & 39 & $22.90 \%$ \\
\hline Exchange of correspondence with tax offices & 28 & $16.50 \%$ \\
\hline Sending declarations customs offices & 26 & $15.30 \%$ \\
\hline Exchange of correspondence with customs offices & 23 & $13.50 \%$ \\
\hline Settling customs liabilities & 15 & $8.80 \%$ \\
\hline Other & 5 & $2.90 \%$ \\
\hline
\end{tabular}


Question 7. Does your enterprise use Internet technologies to support relationships with public administration offices?

\begin{tabular}{|l|c|c|}
\hline & Total & Total \% \\
\hline Downloading forms & 72 & $42.40 \%$ \\
\hline Looking for employees & 62 & $36.50 \%$ \\
\hline Public procurement & 32 & $18.80 \%$ \\
\hline Permits and certificates & 22 & $12.90 \%$ \\
\hline Access to catalogues of public libraries & 21 & $12.40 \%$ \\
\hline Registering vehicles & 19 & $11.20 \%$ \\
\hline Registering business activities & 10 & $5.90 \%$ \\
\hline
\end{tabular}

Question 8. Does your enterprise use the latest systems and information technologies?

\begin{tabular}{|l|c|c|}
\hline & Total & Total \% \\
\hline Communications technologies & 64 & $37.60 \%$ \\
\hline Data warehouses & 50 & $29.40 \%$ \\
\hline Systems of document management & 46 & $27.10 \%$ \\
\hline Technologies supporting group work & 29 & $17.10 \%$ \\
\hline Data mining & 25 & $14.70 \%$ \\
\hline Corporate portals & 22 & $12.90 \%$ \\
\hline Systems of content management & 19 & $11.20 \%$ \\
\hline Business Intelligence Systems & 17 & $10.00 \%$ \\
\hline Multidimensional data analysis - OLAP & 13 & $7.60 \%$ \\
\hline
\end{tabular}

Question 9. In your opinion, what is the greatest barrier in implementation of Internet technologies in business?

\begin{tabular}{|l|r|c|}
\hline & Total & Total \% \\
\hline Lack of knowledge of Internet technologies & 82 & $48.20 \%$ \\
\hline No experience in using Internet technologies in business & 69 & $40.60 \%$ \\
\hline $\begin{array}{l}\text { Lack of knowledge of possibilities to use Internet tech- } \\
\text { nologies in business }\end{array}$ & 52 & $30.60 \%$ \\
\hline No idea how to use Internet technologies in business & 47 & $27.60 \%$ \\
\hline Legal barriers and security related problems & 42 & $24.70 \%$ \\
\hline Technical limitations & 31 & $18.20 \%$ \\
\hline High costs involved & 27 & $15.90 \%$ \\
\hline No need for using Internet technologies & 9 & $5.30 \%$ \\
\hline
\end{tabular}




\section{Appendix B. Existing Knowledge of Possibilities to Implement Internet Technologies in Business - The Questionnaire Research Results}

Question 10. Does your enterprise know legal aspects of using Internet technologies in business?

\begin{tabular}{|l|r|l|}
\hline & Total & Total \% \\
\hline Yes & 98 & $57.60 \%$ \\
\hline No & 72 & $42.40 \%$ \\
\hline
\end{tabular}

Question 11. Does you enterprise know threats and security related issues of using Internet technologies in business?

\begin{tabular}{|l|r|l|}
\hline & Total & Total \% \\
\hline Yes & 132 & $77.60 \%$ \\
\hline No & 38 & $22.40 \%$ \\
\hline
\end{tabular}

Question 12. Does your enterprise know how to implement Internet technologies to support business effectively?

\begin{tabular}{|l|r|c|}
\hline & Total & Total \% \\
\hline No & 90 & $52.90 \%$ \\
\hline Yes & 66 & $38.80 \%$ \\
\hline $\begin{array}{l}\text { We have already implemented } \\
\text { e-business strategies }\end{array}$ & 14 & $8.20 \%$ \\
\hline
\end{tabular}

Question 13. What is the level of knowledge and skills of your enterprise employees with reference to Internet technology utilisation in business?

\begin{tabular}{|l|c|c|}
\hline & Total & Total \% \\
\hline Insufficient & 85 & $50.00 \%$ \\
\hline Sufficient & 75 & $44.10 \%$ \\
\hline High & 10 & $5.90 \%$ \\
\hline
\end{tabular}




\section{Biographies}

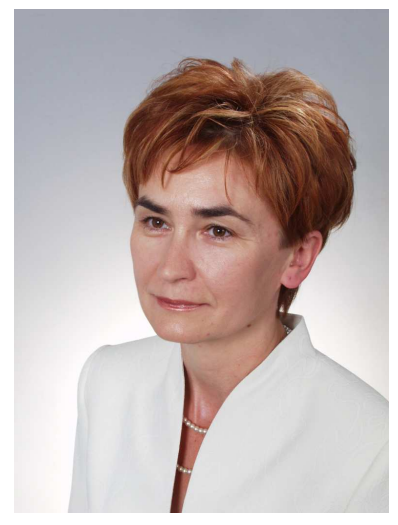

C. M. Olszak is a professor of Business Information Systems at University of Economics in Katowice. She holds MA in Information Systems from Technical University in Wrocław and PhD in Economics from University of Economics in Katowice.

Her special interests include Business Intelligence Systems, data warehouse, Decision Support Systems, knowledge management, e-business, multimedia and Internet technology.

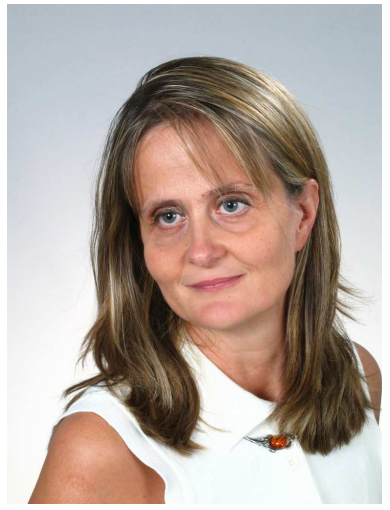

E. Ziemba is an associate professor of Business Information Systems at University of Economics in Katowice. She holds MA in Cybernetics and Computer Science from University of Economics in Katowice and $\mathrm{PhD}$ in Economics from University of Economics in Katowice.

Her special interests include Knowledge Management Systems, corporate portals, Decision Support Systems, e-business and Internet technology. 